\title{
Pericardial and Pleural Effusion in Patient with Relapse Stage IV Breast Cancer: Same Pathology, Different Etiology?
}

\author{
Vienna Rosalinda*, Anggoro Budi Hartopo, Dyah Wulan Anggrahini, Bambang \\ Irawan
}

\author{
Department of Cardiology and Vascular Medicine, Faculty of Medicine, Public Health and Nursing, Universitas Gadjah \\ Mada - Dr. Sardjito Hospital, Yogyakarta, Indonesia \\ * Corresponding authors: \\ Vienna Rosalinda, MD, - email: vienna.rosalinda@gmail.com \\ Department of Cardiology and Vascular Medicine, Faculty of Medicine, Public Health and Nursing, Universitas \\ Gadjah Mada - Dr. Sardjito Hospital \\ Jalan Farmako Sekip Utara, Yogyakarta, Indonesia 55281
}

Manuscript submitted: March 12, 2018; Revised and accepted: May 7, 2018

\section{ABSTRACT}

Pericardial effusion associated with malignacy has poor prognosis. The prompt identification of etiology is mandatory, such that timely management can be performed and survival can be increased. However, difficulty in etiology determination is commonly encountered. In this case, we report female patient with relapse stage IV breast cancer who develop massive pericardial and bilateral pleural effusion. The similar characteristics were found in both effusion fluids, however the identification of etiology was not similar. Metastatic cells were found in pleural effusion, whereas they were absent in pericardial effusion.

Keywords: pericardial effusion; pleural effusion; malignancy; metastatic

\section{INTISARI}

Efusi perikard karena keganasan mempunyai prognosis yang buruk. Identifikasi segera dari etiologi merupakan hal yang utama, karena penatalaksanaan yang tepat waktu dapat dilakukan dan angka harapan hidup meningkat. Namun, kesulitan penentuan etiologi seringkali ditemukan. Pada kasus ini, dilaporkan seorang wanita dengan kanker payudara stadium IV kambuh yang mengalami efusi perikard masif dan efusi pleura bilateran. Kedua efusi mempunyai karakteristik yang mirip, namun identifikasi etiologi tidak menunjukkan kesamaan. Sel-sel metastase ditemukan pada efusi pleura, namun tidak dijumpai pada efusi perikard. 


\section{INTRODUCTION}

Malignancy accounts for $10-25 \%$ of pleural and pericardial effusion. Pericardial effusion in malignancy patients comes from the malignancy itself or due to non malignant process, such as infection, side effect of chemotherapy medication or radiotherapy, and metastatic lymphatic obstruction. ${ }^{1}$ Pericardial effusion due to direct metastatic process has an unfavorable prognosis. The median survival time is five months, according to several studies. ${ }^{1}$ Clinicians are encouraged to determine the etiology of pericardial effusion in patient with malignancy as early as possible, such that appropriate treatment based on the causative pathology could be perfomed timely.

We described a case of pleural and pericardial effusion in woman with relapse stage IV breast cancer, the etiology of pleural effusion was proven metastatic breast cancer whereas that of pericardial effusion was unproven of malignancy process.

\section{CASE REPORT}

A 54 year-old woman presented to our hospital with the chief complaint of progressive dyspnea. She was referred from district hospital. She had been diagnosed with breast cancer in her left breast, confirmed by histopathology examination as ductal infiltrative breast cancer, three years previously. She had had radical mastectomy, 6-cycle adjuvant chemotherapy and 30-session radiotherapy. From the evaluation after chemotherapy and radiotherapy, the tumor was vanished. She routinely had had medical check-up in the oncology outpatient clinics. She was a diabetic patients treated with subcutaneous analog insulin.

Seven month before current admission, she complained the presence of multiple lumps in her neck. The biopsy of the lump revealed relapse breast cancer (ductal carcinoma), with ER (-), PR (-) and Her2 (+++) surface markers. She was diagnosed as stage IV relapse breast cancer, and treated with chemotherapy agents capecitabine and lapatinib. Three month afterward, she complained easily fatigue and dyspnea on effort. The chest $x$ ray examination showed cardiomegaly (figure 1).
The multislice thorax CT scan examination showed mixed type pulmonary metastatic (subpleural, with nodular and pneumonic type metastatic), right sided pleural effusion, pericardial effusion and multiple lymphadenopathy at axilla region). The pleural and pericardial effusion fluids had density level of $15 \mathrm{HU}$ (figure 2).

In the current admission, the blood pressure was $120 / 80 \mathrm{mmHg}$, pulse rate was 110 times/minute and regular, respiration rate was 28 times/minute and axillary temperature was $36.7 \mathrm{C}$. There was no pulsus paradoxus, which indicate there was no cardiac tamponade. The thorax examination showed, decrease tactile fremitus at IV-V intercostal space, dull percussion in IV-V intercostal space of right thorax region. From auscultation, basic respiratory sound was vesicular which was decreased combined with egophony in IV-V left intercostal space. There was no pericardial friction rub. From cardiac physical examination, there was cardiomegaly but no palpable ictus cordis. Right border of the heart was shifted to right parasternal. Left border of the heart was shifted into VII intercostal space along axillary anterior line. In auscultation, no muffle heart sound, and no murmur / gallop sound.

From laboratory examination, the result was unremarkable, except for glucose level of $371 \mathrm{mg} / \mathrm{dl}$. This laboratory result could not eliminate the possibility of infection because she was also treated by capecitabin which had neutropenia effect and might mask the fullblown leukocytosis due to infection. The electrocardiography examination showed sinus tachycardia, normal axis and low voltage (figure 3). The chest $x$-ray demonstrated pericardial effusion with bilateral pleural effusion (figure 4). The transthoracal echocardiography showed massive pericardial effusion, without echo signs of cardiac tamponade (figure 5).

In the first day of hospitalization, the echo-guided subxiphoid access pericardiocentesis was performed and drained approximately $500 \mathrm{~mL}$ of exudative fluid from pericardial space (table 1). The pericardial effusion fluid cytology-pathology examination showed suppurative inflammation without sign of malignant cells. The result of Gram bacterial staining and the acid-fast staining were negative. 


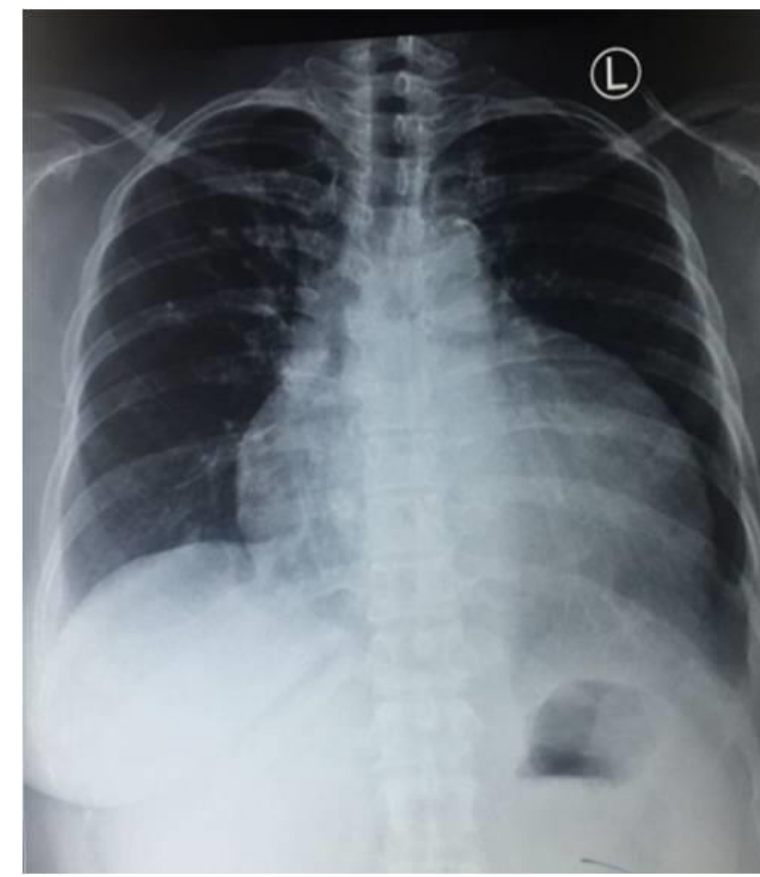

Figure 1. The chest x-ray examination seven month before current admission showed cardiomegaly.

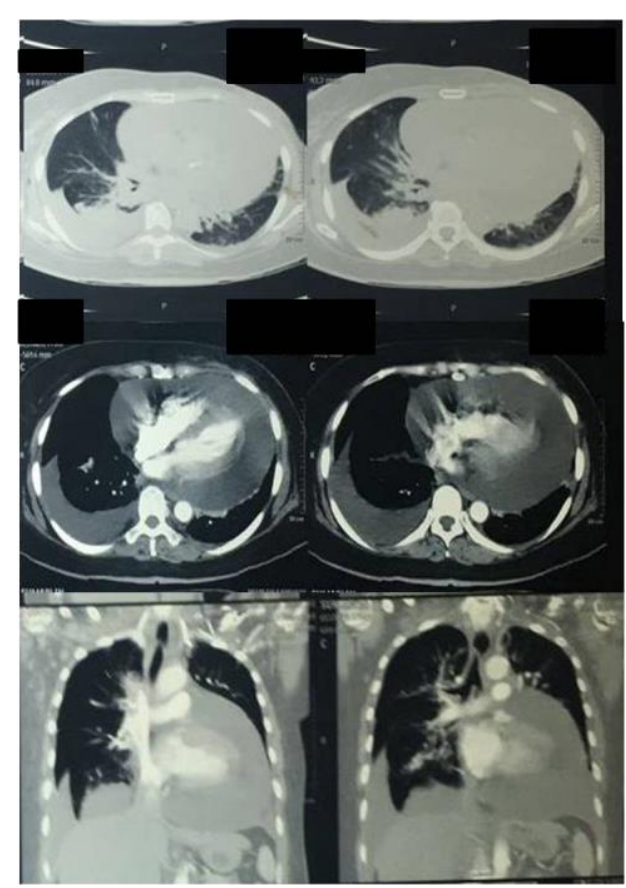

Figure 2. The multislice thorax CT scan examination showed mixed type pulmonary metastatic (subpleural, with nodular and pneumonic type metastatic), right sided pleural effusion and pericardial effusion.

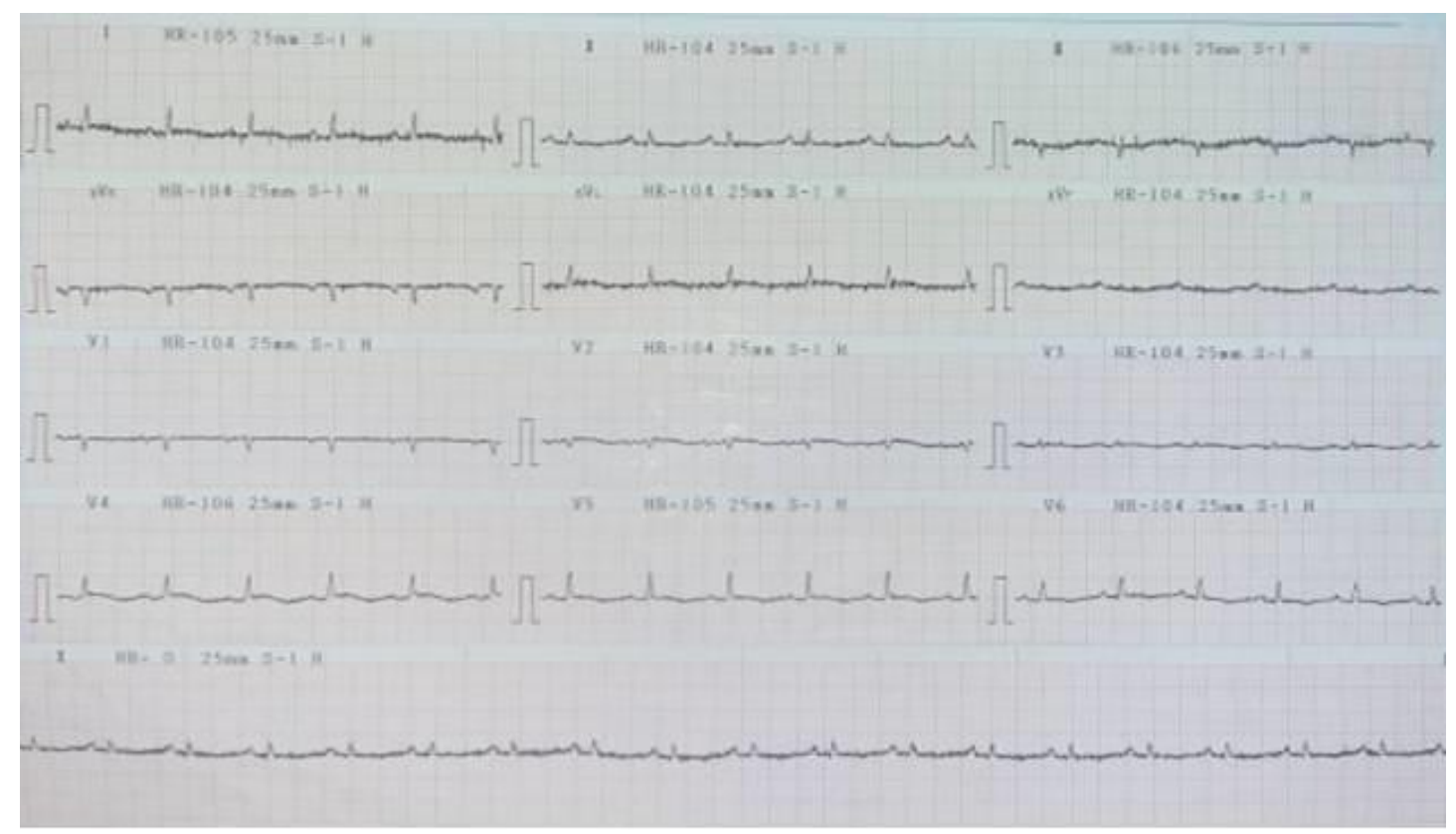

Figure 3. The electrocardiography examination showed sinus tachycardia, normal axis and low voltage. 
The bacterial culture of pericardial effusion fluid was also negative. This patient was managed with subxiphoid pericardial effusion drainage every 8 hours, with pericardial fluid production approximately $150-200 \mathrm{~mL} / 8$ hours. The patient was consulted to pulmonologist. The pleural effusion drainage / thoracentesis was performed. The analysis of pleural effusion fluid showed an exudative fluid (table 1). An adenosine deaminase level was 5.5 (markedly positive if > 30), indicated that there was no tuberculosis. The bacterial culture of pleural effusion fluid resulted in the Staphylococcus epidermidis which was sensitive to ciprofloxacin, levofloxacin, meropenem, tetracycline, vancomicyn, ofloxacin and moxifloxacin. The Gram bacterial staining and acid-fast staining obtained negative result. The cytology-pathology analysis of pleural effusion fluid showed suppurative inflammation and the presence of malignant cells with ductal carcinoma type. This result was in accord with the multislice thorax CT scan which showed pleural type metastatic. From immunological analyze, the anti dsDNA and ANA test were negative. The antibiotics were given based on the fluids analysis.Both the pleural and pericardial fluid analysis revealed similar results, which indicate an exudative characteristics and suppurative infection origin. This result was also supported by the result from multislice thorax CT scan, which showed both pleural and pericardial effusion had similar concentration (15 HU). These similar characteristics indicated that both effusion fluids came from the similar origin. However, the malignant cells were only found in pleural effusion fluid whereas in pericardial fluid was absence despite repetitive cytological examination.

Until ten days hospitalization, the accumulation of drainage product of pericardial effusion was not subsided significantly despite antibiotics treatment for alleged etiology of suppurative infection; therefore the surgical pericardial window was performed by cardiothorax surgeon. The patient underwent surgical pericardial window and during procedure, $500 \mathrm{~mL}$ of pleural fluid and $300 \mathrm{~mL}$ of pericardial fluid were collected. The biopsy of pericardial tissue was performed and the pathology examination showed fibrosis of connective tissue with signs of granulation and chronic

supurative inflammation, no malignant cells were found (Figure 6). The patient was transferred to ICU for recovery. Unfortunately, three days later the patient died in the ICU due to sepsis and pneumonia.

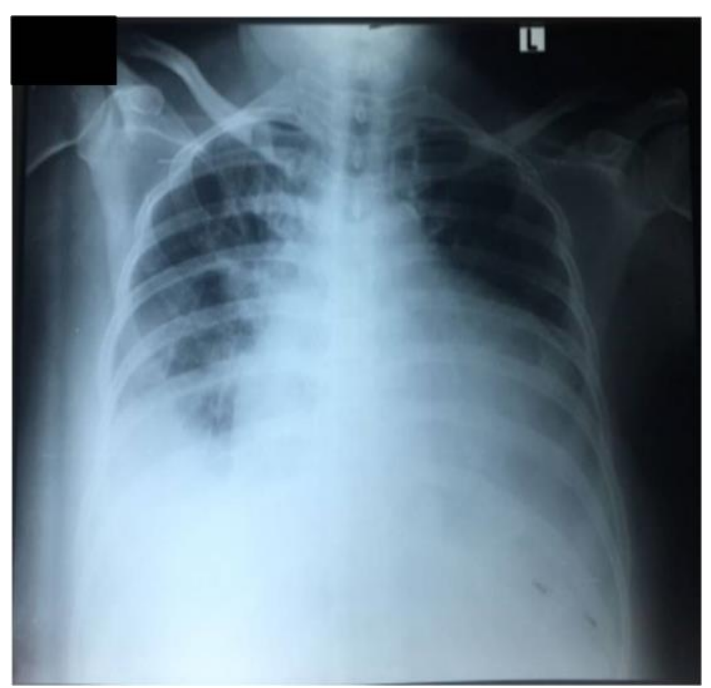

Figure 4. The chest $x$-ray examination on current admission demonstrated pericardial effusion with bilateral pleural effusion. 


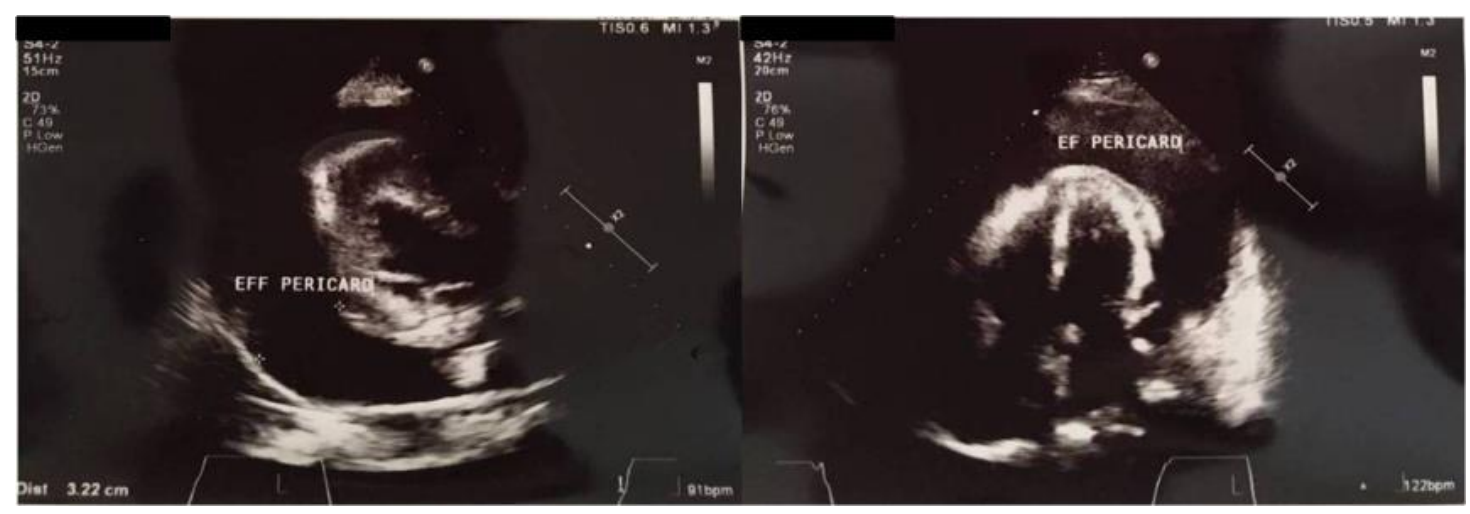

Figure 5. The transthoracal echocardiography showed massive pericardial effusion, without echo signs of cardiac tamponade.

Table 1. Characteristics of pericardial and pleural effusion fluids based on fluids analysis

\begin{tabular}{lcc}
\hline \multicolumn{1}{c}{ Characteristics } & Pericardial Effusion Fluid & Pleural Effusion Fluid \\
\hline protein & $4.19 \mathrm{~g} / \mathrm{dL}$ & $3.43 \mathrm{~g} / \mathrm{dL}$ \\
erythrocyte & $1.000 \mathrm{cells} / \mathrm{mcL}$ & $300 \mathrm{cells} / \mathrm{mcL}$ \\
cells & $110 \mathrm{cells} / \mathrm{mcL}$ & $310 \mathrm{cells} / \mathrm{mcL}$ \\
glucose & $290 \mathrm{mg} / \mathrm{dL}$ & $251 \mathrm{mg} / \mathrm{dL}$ \\
LDH & $778 \mathrm{U} / \mathrm{L}$ & $210 \mathrm{U} / \mathrm{L}$ \\
mononuclear cells & $67 \%$ & $63 \%$ \\
polimorphonuclear & $33 \%$. & $33 \%$ \\
Rivalta test & negative & negative \\
\hline
\end{tabular}

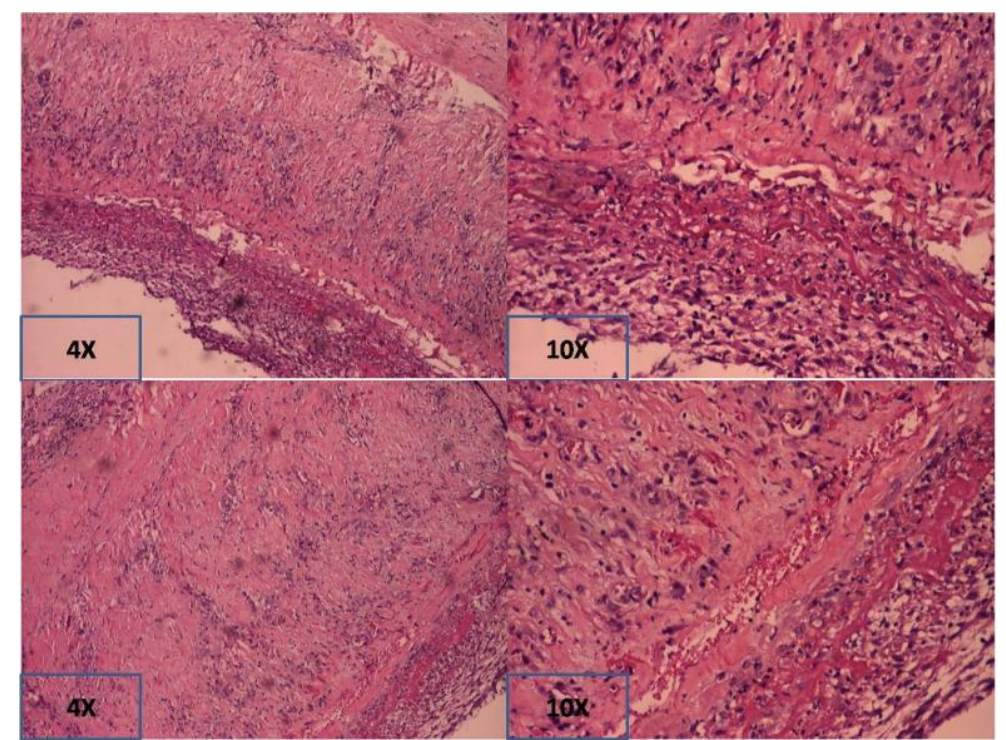

Figure 6. The histopathology of pericardial tissue examination showed a fibrosis of connective tissue with signs of granulation and chronic supurative inflammation, no malignant cells were found 


\section{DISCUSSION}

We report a case of 54-year-old stage IV breast cancer female patient suffered from massive pericardial effusion and bilateral pleural effusion. The initial treatment was echo-guided pericardiocentesis and extended pericardial effusion drainage. The pleural effusion was evacuated with thoracentesis. Both effusion fluids were exudates. The proven etiology of both pericardial and pleural effusions was suppurative infection. The evidence of malignant cells were found in the pleural effusion, whereas in pericardial effusion and tissue were absence. Antibiotic treatment was administered; however the pericardial drainage product was not reduced significantly. Ultimately, the pericardial window with surgery was performed to alleviate the pericardial effusion.

The etiology of pericardial effusion in developing countries is mostly idiopathic $(50 \%)$, infection (15-30\%), malignancy (10$25 \%$, iatrogenic (15-20\%) and autoimmune disease (5-15\%). Among infection, tuberculosis is the common cause of pericardial effusion in the developing countries, which contribute to about $60 \%$ of all causes. ${ }^{2}$ As a common etiology, we worked up the patients with panels of inflammation/infection examination, and concluded that there was suppurative infection as an etiology of pericardial and pleural effusion. Therefore, the antibiotics were admistered. However, they failed to attenuate the pericardial fluids production.

A pericardial effusion may be assessed with multislice thorax CT scan by measuring the level of the attenuation. CT attenuation close to that of water $(<10 \mathrm{HU})$ suggests a transudative effusion. The CT attenuation between 20 to $60 \mathrm{HU}$ indicates purulent, malignant, or myxedematous effusion. The CT attenuation $>60 \mathrm{HU}$ suggest an hemorrhage effusion. ${ }^{3}$ In patients with malignant disease, pericardial involvement may occur by direct tumor invasion or metastatic disease. Multislice thorax CT scan is important in treatment planning and patient's follow-up. ${ }^{2}$ In this patient, the multislice thorax CT scan showed similar CT attenuation in pericardial and pleural effusion, indicating similar characteristics of effusion fluids and may be similar etiology. Purulent/suppurative pericarditis is rare, accounting for $<1 \%$ of cases. The most common organisms were staphylococci, streptococci and pneumococci, while the predominant associated lesions were empyema (50\%) or pneumonia $(33 \%){ }^{2}$ Purulent pericarditis is an indication for urgent pericardiocentesis which is an accurate tool for diagnosis. ${ }^{2}$ The fluid may be noticeably purulent/suppurative. In this case, the suppurative inflammation were detected in both effusions and the positive culture was found in pleural effusion, however based on the bacterial finding we concluded that it came from contamination.

Therapy of pericardial effusion should be targeted at the etiology. Pericardiocentesis or pericardial effusion drainage is indicated for acute cardiac tamponade or suspected bacterial and neoplastic pericarditis. ${ }^{2}$ A study retrospectively evaluated 88 patients who presented with pericardial tamponade associated with a malignancy. It concluded that surgical pericardiotomy with pericardial biopsy did not significantly increase diagnostic value as compared with the cytology-pathology assessment using pericardiocentesis. ${ }^{4}$ Surgical pericardiotomy also did not improve clinical outcomes in comparison with pericardiocentesis and was associated with a increased rate of complications. ${ }^{4}$ Other study involving malignancy cases showed that pericardiocentesis associated with higher recurrence rate as compared with surgical pericardiotomy, however the diagnostic yield and overall complication rate did not significantly differ. 5

Pericardiocentesis with pericardial drainage is safe and effective as the primary treatment for pericardial effusion in patients with malignancy. ${ }^{6} \quad$ Surgical drainage of the pericardium is superior to non-surgical approaches for symptom relief, reduced effusion recurrence and lower morbidity. $^{7}$ In this case, pericardiocentesis and pericardial effusion drainage were performed initially. However, because of the product of pericardial fluid drainage still significant (approximately 150-200 mL/8 hours), the patient was proceeded to surgical pericardial window. The pericardial drainage product is recommended to reduce until $<30 \mathrm{~mL} / 24$ hour to achieve adherence of pericardial layers and prevent accumulation of pericardial fluid again. ${ }^{8}$ If this cannot be achieved, then the surgical pericardial window must be performed. $^{8}$ 
Even after pericardial biopsy, we did not find the proof of malignancy etiology of the pericardial effusion fluid.

\section{CONCLUSION}

We report a case of 54-year-old stage IV breast cancer female patient suffered from massive pericardial effusion and bilateral pleural effusion. The proven etiology of both pericardial and pleural effusion is supurative inflammation / infection. The evidence of malignant cells were found in the pleural effusion, whereas in pericardial effusion and tissue were absent. Antibiotics treatment was administered; however the pericardial drainage product was not reduced significantly. Ultimately, the pericardial window with surgery was performed to alleviate the pericardial effusion.

\section{REFERENCES}

1. Rooper L.M., Ali S.Z., Olson M.T. 2016. A minimum volume of more than $60 \mathrm{ml}$ is necessary for adequate cytology diagnosis of malignant pericardial effusions. Am $\mathrm{J}$ Clin Pathol, 145:101-106.

2. Adler Y., Charron P., Imazio M., Badano L., Barón-Esquivias G., Bogaert J., et al. 2015. ESC Guidelines for the diagnosis and management of pericardial diseases. Eur Heart J, 36:2921-2964.

3. Klein A.L., Abbara S., Agler D.A., Appleton C.P., Asher C.R., Hoit B., et al. 2013. American Society of Echocardiography clinical recommendations for multimodality cardiovascular imaging of patients with pericardial disease. J Am Soc Echocardiogr, 26:965-1012.

4. Patel N., Rafique A.M., Eshaghian S., Mendoza F., Biner S., Cercek B., et al. 2013. Retrospective comparison of outcomes, diagnostic value, and complications of percutaneous prolonged drainage versus surgical pericardiotomy of pericardial effusion associated with malignancy. Am J Cardiol, 112:12351239.

5. Labbé C., Tremblay L., Lacasse Y. 2015. Pericardiocentesis versus pericardiotomy for malignant pericardial effusion: a retrospective comparison. Curr Oncol, 22:412-416.

6. El Haddad D., Iliescu C., Yusuf S.W., William W.N. Jr., Khair T.H., Song J., et al. 2015. Outcomes of cancer patients undergoing percutaneous pericardiocentesis for pericardial effusion. J Am Coll Cardiol, 66:11191128.

7. Jama G.M., Scarci M., Bowden J., Marciniak S.J. 2014. Palliative treatment for symptomatic malignant pericardial effusion. Interact Cardiovasc Thorac Surg, 19:10191026.

8. Imazio M., Adler Y. 2013. Management of pericardial effusion. Eur Heart J, 34:1186-1197. 